\title{
Distillation Method for the Determination of Inorganic Bromide in Cured Tobacco*
}

by L. Toet

Tobacco Research Board, Salisbary, Zimbabwe

\section{INTRODUCTION}

Banks, Desmarchelier and Elek (1) outline four main methods for the analysis of bromide in foodstuffs. These and other methods in the literature indicate that bromide determinations are either time consuming as with iodometric titrations following wet ashings and careful oxidation, expensive in the case of X-ray procedures, or both time consuming and expensive as with neutron activation. A unique alternative method which is rapid, simple and cheap is presented. Values obtained by this selective oxidation method have been compared with neutron activation, X-ray fluorescence and iodometric methods.

\section{METHOD}

\subsection{Samples}

Finely ground cured tobacco leaf $(1 \mathrm{~g})$ is heated slowly (3-4 h) to $450-475^{\circ} \mathrm{C}$ and maintained at that tempera-

Figure 1. Markham still.

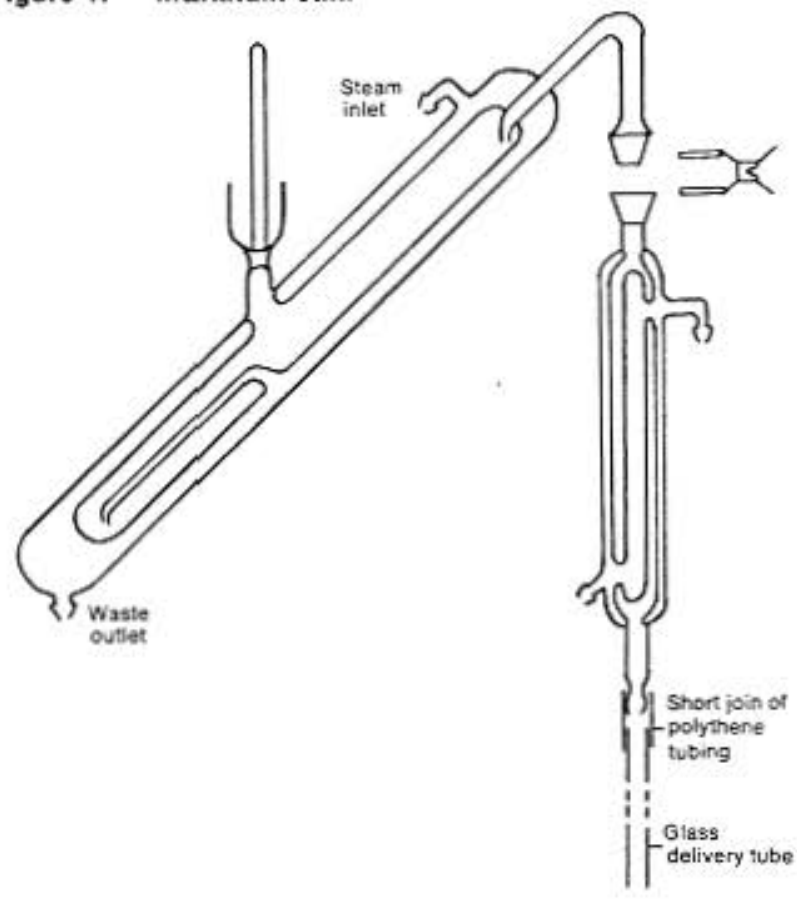

ture until it becomes a white ash, or preferably ashed overnight for 15 hours. The ash is transferred to a Markham still (Figure 1) with a brush through a small glass funnel and is washed down with $5 \mathrm{ml}$ distilled water. A volume of $5 \mathrm{ml}$ oxidising mixture, containing $400 \mathrm{ml}$ $1.25 \mathrm{M}$ aqueous chromium trioxide and $300 \mathrm{ml}$ concentrated sulphuric acid, is added. Steam is admitted to the still where selective oxidation of bromide to bromine takes place and this is distilled into $25 \mathrm{ml}$ of $10 \%$ potassium iodide until $100 \mathrm{ml}$ have been collected. The liberated iodine is titrated with $0.005 \mathrm{~N}$ sodium thiosulphate with a $1 \%$ starch solution as indicator and a $10 \mathrm{ml}$ burette graduated in $0.02 \mathrm{ml}$.

\subsection{Standards and Blanks}

Three standards are made up from A.R. $\mathrm{KBr}$ to contain $0.50 \mathrm{mg}, 1.50 \mathrm{mg}$ and $2.50 \mathrm{mg} \mathrm{Br}^{-}$per $5 \mathrm{ml}$ aliquot. For each Markham still used $5 \mathrm{ml}$ aliquots of the standards as well as $5 \mathrm{ml}$ of distilled water for a blank, are pipetted into the still and distilled and titrated as described. Figure 2 shows batteries of six Markham stills where on each battery the three standards and the blank are determined simultaneously.

Figure 2. Batteries of Markham stills in operation.

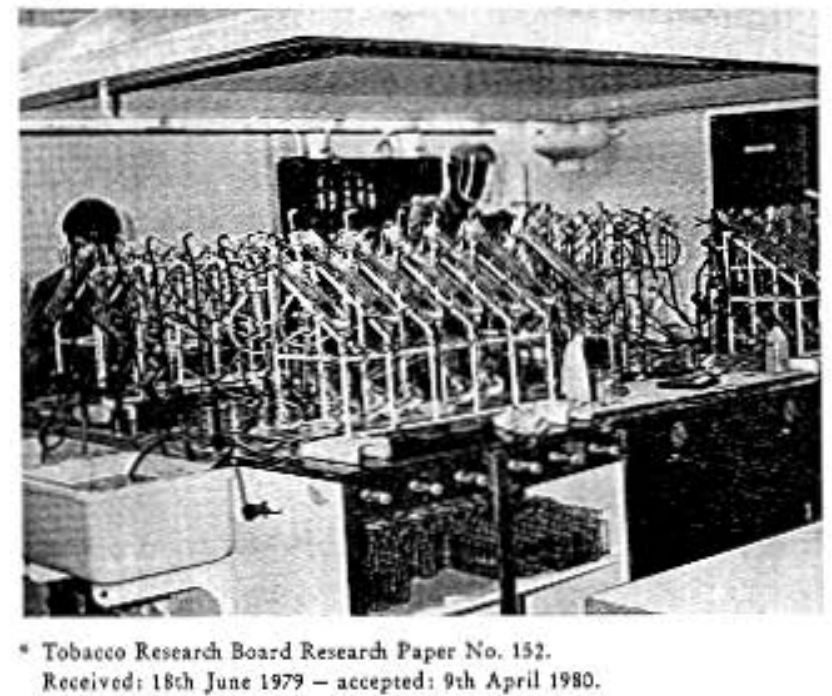




\subsection{Calculation}

A graph of $\mathrm{mg} \mathrm{Br}$ - against titre of sodium thiosulphate is constructed by plotting the titres obtained from the three standards and blanks. The $\mathrm{mg} \mathrm{Br}$ of the $1 \mathrm{~g}$ samples is read from the calibration graph and reported as $\mathrm{mg}$ $\mathrm{Br}^{-} \mathrm{g}^{-1}$.

\section{METHOD VERIFICATION}

\section{1}

Six samples of tobacco, chosen to represent normal and high levels of bromide, were analysed by the distillation method and compared with X-ray fluorescence (2), neutron activation (3), and iodometric (4) analyses conducted by different laboratories. These results are given in Table 1.

Table 1. Comparison of four methods of analysis for bromlde in tobacco samples.

\begin{tabular}{c|c|c|c|c}
\hline \multirow{2}{*}{ Sample } & \multicolumn{4}{|c}{ Bromide (mg/g) } \\
\cline { 2 - 5 } & $\begin{array}{c}\text { Distlla- } \\
\text { tion }\end{array}$ & $\begin{array}{c}\text { X-ray } \\
\text { fluor- } \\
\text { escence }\end{array}$ & $\begin{array}{c}\text { Neutron } \\
\text { activation }\end{array}$ & $\begin{array}{c}\text { lodometric } \\
\text { deter- } \\
\text { mination }\end{array}$ \\
\hline 1 & 0.48 & 0.39 & 0.32 & 0.31 \\
2 & 0.65 & 0.69 & 0.57 & 0.50 \\
3 & 1.43 & 1.55 & 1.29 & 1.20 \\
4 & 2.42 & 2.65 & 2.34 & 2.10 \\
5 & 0.27 & 0.22 & 0.18 & 0.14 \\
6 & 0.21 & 0.18 & 0.15 & 0.13 \\
\hline
\end{tabular}

\section{2}

Ten samples were spiked with bromide at the $3.5 \mathrm{mg} \mathrm{g}^{-1}$ level, ashed and analysed. Recoveries ranged from 93.5 to $102.0 \%$ with a mean of $97.8 \%$.

\section{3}

A series of 14 tobacco samples ranging in bromide content from 0.13 to $4.18 \mathrm{mg} \mathrm{g}^{-1}$ were analysed in triplicate. The variance tended to increase slightly with the level of bromide. The average standard error of a determination was $\pm 0.03 \mathrm{mg} \mathrm{g}^{-1}$.

Table 2. Comparison of bromide concentration detected by lon exchange and distillation methods.

\begin{tabular}{c|c|c}
\hline \multirow{2}{*}{ Sample } & \multicolumn{2}{|c}{ Bromide (mg/g) } \\
\cline { 2 - 3 } & Ion exchange & Distillation \\
\hline 1 & 2.4 & 2.5 \\
2 & 1.6 & 1.7 \\
3 & 0.6 & 0.7 \\
4 & 0.3 & 0.4 \\
5 & 0.4 & 0.5 \\
6 & 0.8 & 0.7 \\
7 & 1.0 & 1.4 \\
8 & 1.9 & 2.4 \\
9 & 0.3 & 0.3 \\
10 & 0.1 & 0.2 \\
\hline
\end{tabular}

Anion exchange chromatography, in which $10 \mathrm{~g}$ of sample was ashed, taken up in water and filtered through a glass wool plug into a column (5) filled with $7 \mathrm{~g}$ anion exchange resin Amberlite CG-400 in the nitrate form. Ten grams of sample spiked at the $3 \mathrm{mg} \mathrm{g}^{-1} \mathrm{Br}$ level was treated in the same way. The chloride was eluted with $0.15 \mathrm{M} \mathrm{NaNO}_{3}$ followed by $0.6 \mathrm{M} \mathrm{NaNO}_{3}$ which elutes the bromide.

Five $\mathrm{ml}$ aliquots of the eluates were titrated potentiometrically with $\mathrm{AgNO}_{3}$ and the results are plotted in Figure 3.

Figure 4 shows the effect when a sample of tobacco is spiked with fluoride, chloride, bromide and iodide. Fluoride elutes from the column before chloride but because its silver salt is soluble it cannot be titrated with $\mathrm{AgNO}_{3}$ and therefore does not feature in Figure 4. Iodide was not detected in any unspiked Rhodesian tobacco samples. Ten samples were analysed by the anion exchange and the distillation methods, the results are given in Table 2. In the ion exchange method, the taking and titration of $5 \mathrm{ml}$ aliquots lead to predictable titration errors and the results have therefore only been expressed to one decimal point. The elution time was about three to four hours per sample, nevertheless the results are of the same order and show the specificity or selectivity of the oxidation medium under the given conditions.

\section{5}

A bromide ion selective electrode was used to measure total bromide concentration in combined fractions of the 0.6 $\mathrm{M} \mathrm{NaNO}_{3}$ eluate (3.4). Table 3 shows the comparisons done on fourteen samples in triplicate. The agreement is not as good as expected because the measurement of $\mathrm{pBr}$ in the eluate from tobacco was not as trouble-free as Banks (1) found using grain and other foodstuffs. The bromide electrode in any solution containing tobacco takes at least ten minutes to stabilize compared with one minute for standard $\mathrm{pBr}$ solutions in $0.6 \mathrm{M}$ sodium nitrate.

\section{6}

To test for possible loss of bromide during the ashing step samples were analysed with and without the addition of calcium oxide which would prevent possible volatilization of the bromide. Table 4 shows four samples analysed ten times in this manner and that the addition of calcium oxide is not necessary as there is no loss of bromide in the ashing process.

\section{7}

The palladium colorimetric method (6) was used to analyse one quality control sample which was also analysed by the distillation method. The results are given in Table 5 and show good agreement between the distillation and palladium method.

\section{8}

The distillation method prescribes the use of $1 \mathrm{~g}$ of sample which is suitable for the normal range of bromide found in tobacco. Samples of $1 \mathrm{~g}$ to $10 \mathrm{~g}$ were ashed and distilled 
Flgure 3. Elution pattern of a $10 \mathrm{~g}$ ashed sample [a] and a $10 \mathrm{~g}$ ashed sample prevlously splked with $3 \mathrm{mg} \mathrm{g}^{-1} \mathrm{Br}$ [b].

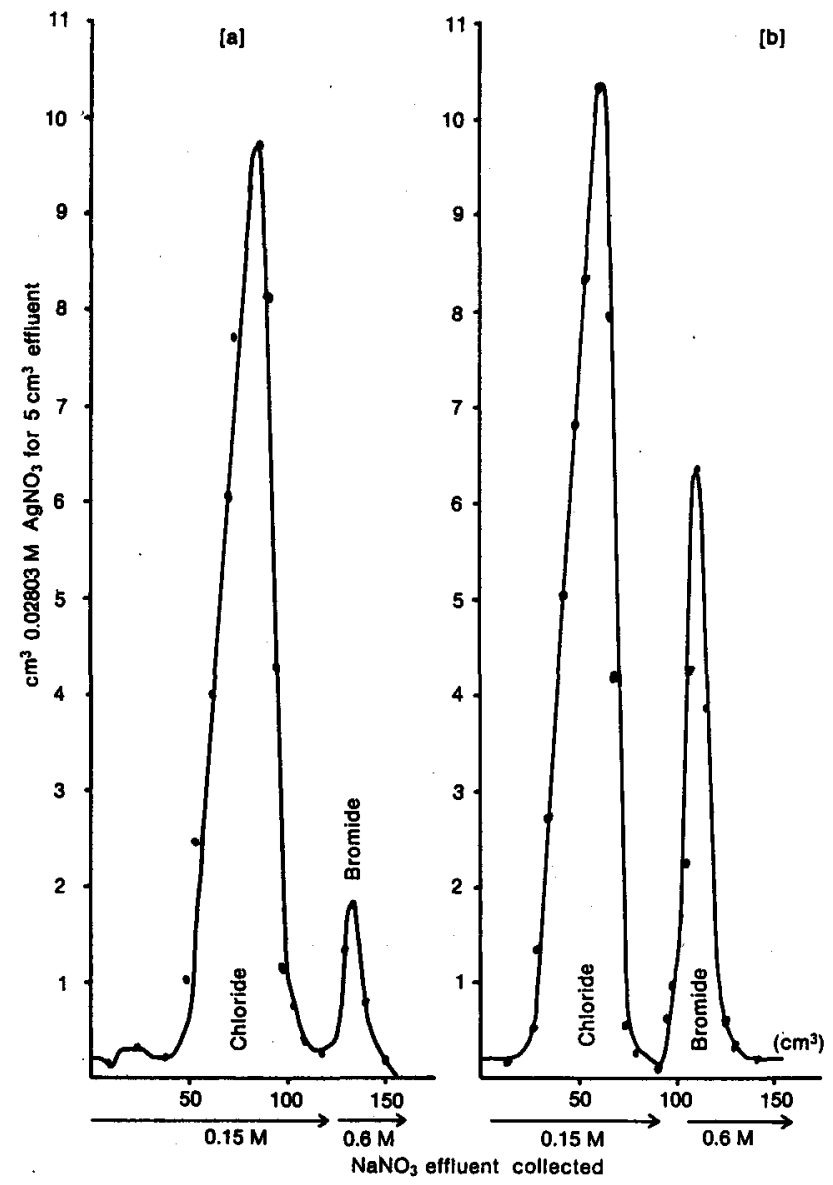

as described to see if the amount of oxidation mixture was still sufficient and if the ash from the larger sample could be accommodated in the Markham still. No difficulty was experienced in transferring even the largest amount of ash to the Markham still and the distillation procedure proceeded as normal. Two samples A and B of widely different bromide concentrations were analysed in duplicate, the results are given in Table 6.

\section{DISCUSSION}

The distillation method has been used with success in the Tobacco Research Board's analytical chemistry department for the last two years.

From thirty to fifty samples can be analysed per day in duplicate including standards and blanks.

The ashing procedure is such that samples can be weighed out in the late afternoon and ashed overnight so that no time is lost in this step. Arrangements are made to switch off the ovens at 4 a.m. so that the samples are cold and ready for distillation when the laboratory opens.

The selective oxidation of bromide in the presence of up to 2000 times its concentration of chloride makes this method particularly useful because chloride levels in fluecured tobacco vary from 3 to $20 \mathrm{mg} \mathrm{g}^{-1}$, whereas the highest bromide encountered from experimental plots is $5 \mathrm{mg} \mathrm{g}^{-1}$ and the values of bromide in tobacco grown on virgin soil range from 0.01 to $0.3 \mathrm{mg} \mathrm{g}^{-1}$. Bromide in commercial, locally grown tobacco after fumigation with
Figure 4. Graph of the separation of fluoride, chlorlde, bromlde and lodide by anlon exchange chromatography.

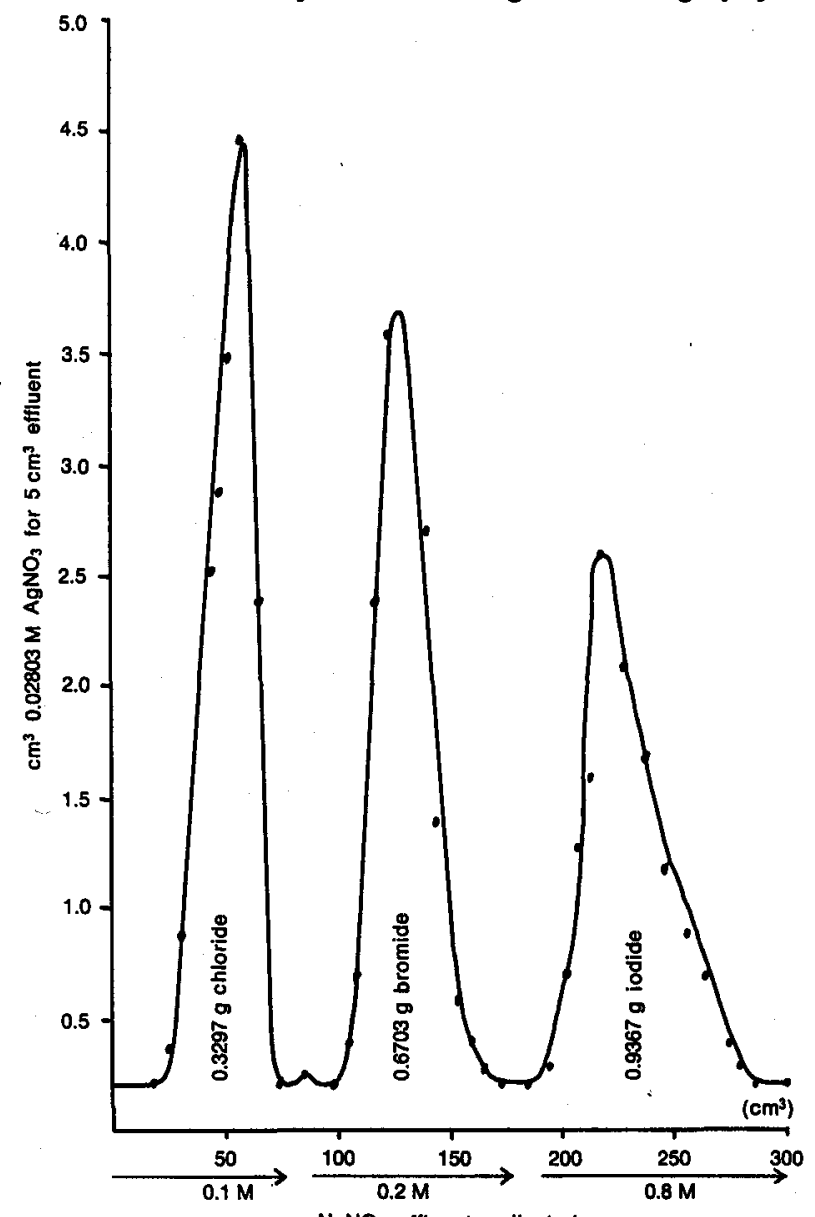

$\mathrm{NaNO}_{3}$ effluent collected

methyl bromide and/or ethylene dibromide normally ranges from 0.5 to $2.0 \mathrm{mg} \mathrm{g}^{-1}$. In the method, a sample mass of $1 \mathrm{~g}$ ensures that most samples give titres within the range of the three standards. It is quite possible, however, to increase the mass to as high as $10 \mathrm{~g}$, catering for very low bromide values. Table 6 shows good agreement from $1 \mathrm{~g}$ to $10 \mathrm{~g}$. The ash from $10 \mathrm{~g}$ of tobacco can still be readily transferred to the Markham still and therefore the range of bromide detection can be increased without any difficulty. The results of the analysis of six samples by distillation, X-ray fluorescence, neutron activation and iodometric analyses (Table 1) show that although the results are of the same order, if the standard deviation of all the methods is about equal $\left(0.03 \mathrm{mg} \mathrm{g}^{-1}\right)$, the methods give significantly different answers at the $95 \%$ confidence level. The author has no immediate explanation for this.

The photograph (Figure 2) shows the banks of Markham stills which are also used for the determination of nicotine and nitrogen.

The extra capital outlay in our laboratory was therefore nil and would be small for any laboratory wishing to set up this apparatus. It should be noted that in the Markham still assembly (Figure 1) the delivery tube is connected to the condenser with a short piece of polythene tubing, giving almost a glass to glass connection because poor recoveries were obtained, due to absorption of bromide, when using polythene delivery tubes. 
Table 3. Comparison of bromide concentration found by distillation and specific Ion electrode methods.

\begin{tabular}{|c|c|c|c|c|c|c|c|c|c|}
\hline \multirow{2}{*}{ Sample } & \multicolumn{4}{|c|}{ Bromide (mg g-1) } & \multirow{2}{*}{ Sample } & \multicolumn{4}{|c|}{ Bromide $\left(\mathrm{mg} \mathrm{g}^{-1}\right)$} \\
\hline & \multicolumn{2}{|c|}{$\begin{array}{l}\text { Distlllation } \\
\text { method }\end{array}$} & \multicolumn{2}{|c|}{$\begin{array}{l}\text { Specific ion } \\
\text { electrode }\end{array}$} & & \multicolumn{2}{|c|}{$\begin{array}{l}\text { Distillation } \\
\text { method }\end{array}$} & \multicolumn{2}{|c|}{$\begin{array}{l}\text { Specific ion } \\
\text { electrode }\end{array}$} \\
\hline \multirow[t]{4}{*}{1} & & 0.18 & & 0.18 & 8 & & 0.61 & & $0.5 \uparrow$ \\
\hline & & 0.17 & & 0.26 & & & 0.57 & & 0.40 \\
\hline & & 0.16 & & 0.21 & & & 0.62 & & 0.44 \\
\hline & mean & 0.17 & mean & 0.22 & & mean & 0.60 & mean & 0.45 \\
\hline \multirow[t]{4}{*}{2} & & 0.13 & & 0.12 & 9 & & 0.97 & & 0.84 \\
\hline & & 0.13 & & 0.11 & & & 0.98 & & 0.81 \\
\hline & & 0.14 & & 0.13 & & & 0.96 & & 0.83 \\
\hline & mean & 0.13 & mean & 0.12 & & mean & 0.97 & mean & 0.83 \\
\hline \multirow[t]{4}{*}{3} & & 0.57 & & 0.62 & 10 & & 1.06 & & 1.10 \\
\hline & & 0.61 & & 0.52 & & & 1.09 & & 1.14 \\
\hline & & 0.58 & & 0.52 & & & 1.12 & & 1.10 \\
\hline & mean & 0.59 & mean & 0.55 & & mean & 1.09 & mean & 1.11 \\
\hline \multirow[t]{4}{*}{4} & & 0.33 & & 0.21 & 11 & & 1.47 & & 1.59 \\
\hline & & 0.32 & & 0.33 & & & 1.53 & & 1.48 \\
\hline & & 0.32 & & 0.25 & & & 1.46 & & 1.38 \\
\hline & mean & 0.32 & mean & 0.26 & & mean & 1.49 & mean & 1.48 \\
\hline \multirow[t]{4}{*}{5} & & 0.47 & & 0.41 & 12 & & 2.75 & & 2.33 \\
\hline & & 0.46 & & 0.37 & & & 2.75 & & 2.27 \\
\hline & & 0.44 & & 0.37 & & & 2.62 & & 2.20 \\
\hline & mean & 0.46 & mean & 0.38 & & mean & 2.71 & mean & 2.27 \\
\hline \multirow[t]{4}{*}{6} & & 0.52 & & 0.42 & 13 & & 3.64 & & 3.36 \\
\hline & & 0.48 & & 0.39 & & & 3.62 & & 3.49 \\
\hline & & 0.47 & & 0.43 & & & 3.61 & & 3.34 \\
\hline & mean & 0.49 & mean & 0.41 & & mean & 3.62 & mean & 3.40 \\
\hline \multirow[t]{4}{*}{7} & & 0.58 & & 0.41 & 14 & & 4.15 & & 3.68 \\
\hline & & 0.61 & & 0.33 & & & 4.20 & & 3.52 \\
\hline & & 0.54 & & 0.43 & & & 4.20 & & 3.98 \\
\hline & mean & 0.54 & mean & 0.34 & & mean & 4.18 & mean & 3.73 \\
\hline
\end{tabular}

Table 4. Comparison of bromide detected in four tobacco samples after ashing with calclum oxlde [A]* and without calclum oxlde [B].

\begin{tabular}{|c|c|c|c|c|c|c|c|c|}
\hline \multirow{3}{*}{ No. } & \multicolumn{8}{|c|}{ Bromide $\left(\mathrm{mg} \mathrm{g}^{-1}\right)$} \\
\hline & \multicolumn{2}{|c|}{1} & \multicolumn{2}{|c|}{ II } & \multicolumn{2}{|c|}{ III } & \multicolumn{2}{|c|}{ IV } \\
\hline & A & B & A & B & A & B & A & B \\
\hline 1 & 2.46 & 2.50 & 1.70 & 1.71 & 0.78 & 0.79 & 0.41 & 0.46 \\
\hline 2 & 2.58 & 2.62 & 1.67 & 1.72 & 0.73 & 0.77 & 0.48 & 0.45 \\
\hline 3 & 2.41 & 2.53 & 1.64 & 1.65 & 0.72 & 0.80 & 0.57 & 0.53 \\
\hline 4 & 2.55 & 2.51 & 1.63 & 1.69 & 0.73 & 0.74 & 0.43 & 0.61 \\
\hline 5 & 2.53 & 2.58 & 1.69 & 1.68 & 0.71 & 0.73 & 0.41 & 0.44 \\
\hline 6 & 2.54 & 2.52 & 1.69 & 1.72 & 0.79 & 0.71 & 0.44 & 0.45 \\
\hline 7 & 2.56 & 2.51 & 1.63 & 1.61 & 0.73 & 0.74 & 0.46 & 0.48 \\
\hline 8 & 2.49 & 2.50 & 1.68 & 1.70 & 0.76 & 0.73 & 0.49 & 0.43 \\
\hline 9 & 2.53 & 2.52 & 1.60 & 1.77 & 0.75 & 0.76 & 0.43 & 0.42 \\
\hline 10 & 2.50 & 2.57 & 1.69 & 1.73 & 0.82 & 0.78 & 0.42 & 0.46 \\
\hline Mean & 2.51 & 2.54 & 1.66 & 1.70 & 0.76 & 0.76 & 0.45 & 0.47 \\
\hline
\end{tabular}

"All the "A" samples were prepared betore ashing by intimately mixing $1 \mathrm{~g}$ of tobacco sample with $1 \mathrm{~g}$ of A.R. CaO. 
Table 5. Comparieon of bromide concentration using the palladium and distillation methods on one quality control sample.

\begin{tabular}{c|c}
\hline \multicolumn{2}{c}{ Bromide $\left(\mathrm{mg} \mathrm{g}^{-1}\right)$} \\
\hline Palladium method & Distillation method \\
\hline 1.6 & 1.5 \\
1.6 & 1.6 \\
1.5 & 1.6 \\
1.4 & 1.6 \\
1.5 & 1.6 \\
1.5 & 1.6 \\
1.5 & 1.6 \\
1.6 & 1.6 \\
1.2 & 1.6 \\
1.5 & 1.6 \\
1.6 & 1.6 \\
1.6 & 1.6 \\
1.5 & 1.7 \\
1.5 & 1.6 \\
\hline Mean 1.5 & 1.6 \\
\hline
\end{tabular}

Table 6. Bromide concentration detected in different masses of allquot from two samples of tobacco.

\begin{tabular}{|c|c|c|}
\hline \multirow{2}{*}{$\begin{array}{c}\text { Mass } \\
(g)\end{array}$} & \multicolumn{2}{|c|}{ Bromide $\left(\mathrm{mg} \mathrm{g}^{-1}\right)$} \\
\hline & Sample A & Sample B \\
\hline 1 & $\begin{array}{l}0.15 \\
0.17\end{array}$ & $\begin{array}{l}2.00 \\
1.97\end{array}$ \\
\hline 2 & $\begin{array}{l}0.15 \\
0.16\end{array}$ & $\begin{array}{l}2.05 \\
2.06\end{array}$ \\
\hline 3 & $\begin{array}{l}0.15 \\
0.16\end{array}$ & $\begin{array}{l}2.04 \\
2.02\end{array}$ \\
\hline 4 & $\begin{array}{l}0.16 \\
0.15\end{array}$ & $\begin{array}{l}2.07 \\
2.05\end{array}$ \\
\hline 5 & $\begin{array}{l}0.15 \\
0.16\end{array}$ & $\begin{array}{l}2.12 \\
2.02\end{array}$ \\
\hline 6 & $\begin{array}{l}0.15 \\
0.16\end{array}$ & $\begin{array}{l}1.93 \\
1.94\end{array}$ \\
\hline 7 & $\begin{array}{l}0.15 \\
0.15\end{array}$ & $\begin{array}{l}1.95 \\
2.13\end{array}$ \\
\hline 8 & $\begin{array}{l}0.13 \\
0.16\end{array}$ & $\begin{array}{l}2.02 \\
1.86\end{array}$ \\
\hline 9 & $\begin{array}{l}0.17 \\
0.17\end{array}$ & $\begin{array}{l}1.97 \\
1.99\end{array}$ \\
\hline 10 & $\begin{array}{l}0.16 \\
0.17\end{array}$ & $\begin{array}{l}1.95 \\
1.93\end{array}$ \\
\hline
\end{tabular}

\section{SUMMARY}

A rapid, reliable and inexpensive method for the determination of inorganic bromide in cured tobacco is presented. The method features a unique $\mathrm{CrO}_{3}$ selective oxidation with steam in Markham stills. The results by this method have been compared with five other methods. The reliability of the distillation method is shown by the recoveries of spiked samples at a mean of $97.8 \%$. The average standard error of $\pm 0.03 \mathrm{mg} \mathrm{g}^{-1}$ indicates an acceptable level of precision. No loss of bromide takes place in the ashing process.

\section{ZUSAMMENFASSUNG}

Zur Bestimmung von anorganischem Bromid in getrocknetem Tabak wird eine schnell, zuverlässig und kostengünstig arbeitende Methode vorgestellt. Das Verfahren basiert auf einer selektiven Oxidation von Bromid zu Brom mit $\mathrm{CrO}_{3}$ in einer Destillationsanlage der Firma Markham. Die mit dieser Methode erhaltenen Ergebnisse werden mit denen fünf anderer Verfahren verglichen. Bei mit Bromid angereicherten Proben ergab sich durchschnittlich eine Wiederauffindungsrate von $97,8 \%$, wodurch die Zuverlässigkeit der Destillationsmethode bewiesen ist. Die mittlere Standardabweichung lag bei $\pm 0,03 \mathrm{mg} \mathrm{g}^{-1}$, wodurch sich eine ausreichende Genauigkeit anzeigt. Während des Veraschungsprozesses wurde kein Verlust an Bromid beobachtet.

\section{RESUME}

On présente une méthode peu coûteuse, rapide et fiable pour la détermination du bromure inorganique dans le tabac «cured». La méthode est basée sur une oxidation sélective au moyen de $\mathrm{CrO}_{3}$ dans un appareil à distiller Markham. Les résultats obtenus par cette méthode sont comparés à ceux de 5 autres méthodes. La fiabilité de la méthode par distillation est démontrée au moyen d'échantillons enrichis de bromure, retrouvé en moyenne à 97,8\%. L'écart-type moyen de $\pm 0,03 \mathrm{mg} \mathrm{g}^{-1}$ représente un niveau de precision acceptable. L'incinération du tabac n'entraîne pas de perte de bromure.

\section{REFERENCES}

1. Banks, H. J., J. M. Desmarchelier and J. A. Elek: Pesticide Science 7 (1976) 595-603.

2. Bergström, C., and O. Bakker: Private communication (P.O. Box 426, Bedfordview 2008, Johannesburg, Republic of South Africa).

3. Schelenz, B., and E. Fischer: Neutronenaktivierungsanalyse von Spurenelementen in Lebensmitteln; Berichte der Bundesforschungsanstalt für Ernährung, Karlsruhe, BFE-Bericht 1976/4, 63.

4. Turner, A.: J. Sci. Food Agr. 15 (1964) 265.

5. Toet, M. J., and L. Toet: Beitr. Tabakforsch. 8 (1976) 334-338.

6. Toet, L.: Unpublished results (Tobacco Research Board, halide methods).

\section{Acknowledgements}

The author would like to thank Dr. Fischer, Mr. R. Schelenz, Dr. M. Salta, Mr. C. Bergström and Dr. Wittekindt for the analysis of tobacco samples by neutron activation, iodometric and $X$-ray fluorescence methods and for giving permission to use the results.

Author's address:

Tobacco Research Board, P. O. Box 1909, Salisbury, Zimbabwe. 